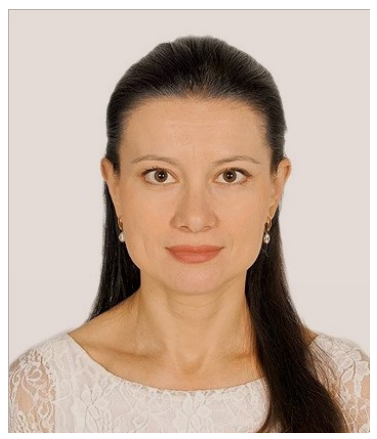

\author{
L. Kobak, O. Abrahamovych, U. Abrahamovych, \\ V. Chemes
}

Danylo Halytsky Lviv National Medical University

\title{
Modern View on the Problem of Systemic Lupus Erythematosus with and without Comorbid Lesions of the Circulatory System (Literature Review, Clinical Case Description) - Second Notice
}

Clinical case description. Patient S., 43 yo, saleswoman, from Lviv. She was hospitalized in 2018 with complaints of pain in the knee and ankle joints, small joints of the hands and feet, recurrent pain in the occipital region, which was probably caused by high blood pressure and general weakness.

From the anamnesis of the disease - the patient in 2000 began to suffer from pain in the knee, ankle, shoulder and wrist joints, swelling and redness of the skin over the affected joints; and an erythematous rash on the face in the areas of cheeks and nose back. She was diagnosed with SLE at the cardio-rheumatology department (Kyiv). Because of her persistent and deteriorating condition, she has been under constant inpatient and outpatient treatment The patient underwent renal biopsy on November 26, 2010, which confirmed lupus glomerulonephritis. Due to her disease deterioration, she was hospitalized at the rheumatology department of the Municipal Non-Profit Enterprise of the Lviv Regional Council "Lviv Regional Clinical Hospital".

Life anamnesis: childhood diseases - chickenpox, acute respiratory viral infections, frequent sore throats, measles, rubella. Tuberculosis, sexually transmitted diseases, viral hepatitis; malaria, diabetes were denied. Heredity is not burdened. Patient did not observe any allergies to drugs. Patient denies occupational hazards, smoking, alcohol consumption. Surgical interventions: cesarean section (1996, 2003), tonsillectomy (2008).

Objective examination. General condition - moderate severity. Height $-165.0 \mathrm{~cm}$. Body weight $-99.0 \mathrm{~kg}$. Body mass index - 36.4. The constitution is hypersthenic. The position in bed is active. Mucous membranes are moist. Skin - reticular livedo. Lymph nodes available for palpation, are not enlarged, painless, covered with unaltered skin. Respiratory system: respiratory rate - 19/min. Pal- pation of the chest is painless, elastic, vocal tremor is carried out equally over symmetrical areas. Percussion sound over the lungs - clear lung. Breathing - vesicular, no wheezing. Circulatory system: apical beat in the $\mathrm{V}$ intercostal space, $1.5 \mathrm{~cm}$ medial to the left midclavicular line. The heart rhythm is correct, the heart tones are rhythmic. Heart rate (HR) - $80 \mathrm{bpm}$, pulse - 80 per $1 \mathrm{~min}$, of sufficient filling and tension. Blood pressure (BP) - 170/100 $\mathrm{mmHg}$ on both hands. Digestive organs: the tongue is wet, the teeth are sanitized, the tonsils are removed surgically. Abdomen is of normal shape, palpably soft, painless, the lower edge of the liver protrudes from the edge of the costal margin by $1.0 \mathrm{~cm}$, sharp, soft, smooth, the size of the liver according to M. G. Kurlov - 10.0 × 9.0 x $8.0 \mathrm{~cm}$; the spleen is not enlarged; intestine is elastic, soft, and painless. Urinary organs: kidneys are not palpable. F. I. Pasternatsky sign is negative on both sides; legs are a little bit swollen. There are no dysuric problems. Musculoskeletal system: joints are without deformation, no swelling of periarticular tissues; the amount of active and passive movements is a little bit limited in aching joints. The strength of the hands is preserved. The pace is not disturbed. Skeletal muscle tone is preserved.

The patient underwent laboratory and instrumental examinations and revealed the following deviations from the norm:

1) complete blood count: decrease of the number of leukocytes to $2.3 \times 10^{9} / 1\left(4.3-10.0 \times 10^{9} / 1\right)$;

2) urinalysis - slight increase of protein content to 0.331 (absent);

3) biochemical blood analysis - increase of C-reactive protein content to $20.4 \mathrm{mg} / \mathrm{l}$ (less than $5.0 \mathrm{mg} / \mathrm{l}$ ), antistreptolysin "O" - to 500.0 AO (less than 250.0 AO), rheumatoid factor - to $13.7 \mathrm{IU} / \mathrm{ml}$ (absent), low-density lipoproteins - to $3.5 \mathrm{mmol} / \mathrm{l}$ (less than $2.6 \mathrm{mmol} / \mathrm{l}$ ), triglycerides 
-to $2.91 \mathrm{mmol} / 1$ (less than $2.28 \mathrm{mmol} / \mathrm{l})$, atherogenity in $\neg$ dex - to 4.1 (less than 3.0), AST - to 53 IU/1 (less than 31.0 IU/1); ALT - to 62 IU/1 (less than $33.0 \mathrm{IU} / 1)$; alkaline phosphatase - to 124 units/1 (less than 98.0 units/1); decrease of high-density lipoproteins content to $0.97 \mathrm{mmol} / 1$ (more than $1.68 \mathrm{mmol} / \mathrm{l}$ );

4) coagulogram - increase of total fibrinogen to $4.8 \mathrm{~g} / 1$ (less than $4.0 \mathrm{~g} / 1$ );

5) immunological blood analysis - increase of the contents of anti-dsDNA to $173.7 \mathrm{IU} / \mathrm{ml}$ (less than $35 \mathrm{IU} / \mathrm{ml}$ ), ANA - to $4.8 \mathrm{IU}$ (less than 1.0 IU), small circulating complexes - to 420 units. (300-400 units), APLA IgG - to $18.0 \mathrm{IU} / \mathrm{ml}$ (less than $10 \mathrm{IU} / \mathrm{ml})$, APLA IgM - to $24 \mathrm{IU} /$ $\mathrm{ml}$ (less than $10 \mathrm{IU} / \mathrm{ml}$ ), lupus erythematosus (LE) cells were detected solitary (absent);

6) ECG: sinus rhythm, heart rate - $78 \mathrm{bpm}$, the normal electrical axis, no ischemic changes;

7) Echocardiography: hypertrophy of the basal part of the interventricular septum, left ventricle, the overall contractility of the left ventricle is preserved $(\mathrm{EF}=64.0$ $\%$ ); no pulmonary hypertension; no free fluid in the pleural sinuses;

8) daily monitoring of blood pressure - during the day the average systolic and diastolic blood pressure (SBP, DBP) were 158 and $97 \mathrm{mmHg}$ in accordance. The maximal SBP and DBP were $186 \mathrm{mmHg}$ and $135 \mathrm{mmHg}$ per day accordingly, the minimal - $108 \mathrm{mmHg}$ and $61 \mathrm{mmHg}$ in accordance. During the active period, the average SBP and DBP were 165 and $90 \mathrm{mmHg}$ respectively, during the passive - 143 and $81 \mathrm{mmHg}$ in accordance. The variability of SBP and DBP during the day was increased. Insufficient lowering of blood pressure at night was observed. During the day, SBP exceeded the upper limit in $34.0 \%$ of measurements, DBP - in $37.0 \%$ of measurements. Pulse blood pressure was increased (61 $\mathrm{mmHg})$. The average daily heart rate was $82 \mathrm{bpm}$;

9) ultrasound examination of the internal organs: liver - right lobe thickness is $159.0 \mathrm{~mm}$, the structure is homogeneous, echogenicity is increased, signs of fatty steatohepatitis; portal vein is normal; choledochus is normal; gallbladder - normal sizes, wall - $3.0 \mathrm{~mm}$, without stones; pancreas - sizes within the normal limits, structure is homogeneous, echogenicity is normal, contour is smooth; spleen - without changes; kidneys - normal sizes, cup-pelvic system is not expanded, not blocked, parenchyma $16.0 \mathrm{~mm}$; the urinary bladder is not filled;

10) ultrasound of the thyroid gland: right lobe $-39.0 \times 16.0 \times 15.7 \mathrm{~mm}$, left lobe - 39.0x15.0x15.2 mm, isthmus $-3.5 \mathrm{~mm}$; the structure is homogeneous; lymph nodes are not enlarged; blood flow is moderate;

11) ultrasound of the pelvic organs: no pathological changes;

12) ultrasound of the breasts: no pathological changes;

13) ultrasound of the aortic arch branches: the branches of the aortic arch are localized in typical places; S-shaped deviation of both internal carotid arteries with hemodynamic disturbance as in case of 50.0-55.0 \% stenosis can be seen on the left side, the walls are thickened; intima-media complex - 0.9-1.1 mm; 25.0-30.0\% stenosis of the bifurcation of the right common carotid artery through a solid plaque with an uneven contour; $25.0 \%$ stenosis of bifurcation of the left common and internal carotid artery due to the small calcificated plaque with an uneven contour; Doppler examination of the extracranial sections of the vertebral arteries revealed moderate extravasal compression of the right and expressed left vertebral artery; on the subclavian arteries the blood flow is main. Conclusion: deviation of both internal carotid arteries, atherosclerosis of the carotid arteries;

14) spirometry: dysfunction of external respiration is not detected;

15) X-ray of the chest organs: lungs and heart are without visible pathological changes;

16) X-ray of the hands: signs of polyosteoarthritis of the joints of the hands (0-I degree): moderate, epiphyseal osteoporosis; relative narrowing of the articular fissures of the interphalangeal joints; articular surfaces are clear, moderately compacted;

17) nephrobiopsy: diffuse mesangiocapillary proliferative lupus glomerulonephritis (class IV C - modified WHO classification, 1995) (LN IV-S, A/C - classification of lupus nephritis, developed by international associations of nephrologists and pathomorphologists in 2003).

Consultations of the related specialists: 1) consultation of the cardiologist: patient has arterial hypertension: stage II (left ventricular (LV) hypertrophy), degree 3, risk 2 (moderate), heart failure (HF) 0 . Obesity of the second degree, acquired dyslipidemia (IIb by D. Fredrickson, 1970); 2) consultation of the nephrologist - SLE: subacute course, activity of the first degree; chronic kidney disease CKD (stage I: diffuse mesangiocapillary proliferative lupus glomerulonephritis (class IV C); chronic renal failure (CRF) 0 degree); 3) consultation of the gastroenterologist - the patient has chronic steatohepatitis, incomplete remission phase, digestive insufficiency (DI) 0 degree; 4) consultation of the dentist: the oral cavity is sanitized; 5 ) consultation of the otolaryngologist - the state after tonsillectomy; 6) consultation of the ophthalmologist retinal angiopathy, "dry eye syndrome" of both eyes.

Based on the received results of the examinations, applying the method of determining the functional class (FC) of SLE [1-3], the patient was diagnosed with a clinical diagnosis: 1) main - M.32.1. "SLE: active phase, II activity degree (according to SLEDAI); chronic course with severity increase; with the history of the lesion of skin ("butterfly" in the anamnesis); joints (arthralgia of the hands and feet, FJI I); kidneys (CKD: stage I, diffuse mesangiocapillary proliferative lupus glomerulonephritis (class IV C - modified WHO classification, 1995), stable remission phase, CRF: 0 degree); vessels (reticular livedo); blood system (leukopenia); immune system (anti-dsDNA-positive, ANA-positive, APLS); eyes ("dry eye syndrome"); complicated by: arterial hypertension: secondary (renoparenchymal + drug-induced), stage II (left ventricular hypertrophy, retinal angiopathy), stage II, risk II (moderate), HF: 0 - I stage, (I FC according to NYHA); SLE FC: I"; 2) concomitant - "chronic steatohepatitis, incomplete remission phase, DI: 0 degree; obesity: 2nd degree; acquired dyslip- 
idemia (IIb according to D. Fredrickson, 1970); state after tonsillectomy (2008). FC of a therapeutic patient: I - II".

Notes: FJI - functional joints insufficiency; DI - digestive insufficiency.

The patient was prescribed with a complex pathogenetic treatment taking into account the damage to the circulatory system, the treatment was added by the combined antihypertensive treatment, statin, cardioprotector: ward regimen; diet N 10 according to M. Pevzner; Thiotriazoline, Hepadif, Tivortin, Prednisolone, Plaquenil, Omeprazole, Hartil, Amlodipine, Rosulip.

After the inpatient treatment, home recommendations were also given. The patient was under the constant dynamic observation.

According to the results of the prospective study during three years, the general condition of the patient improved, clinical and laboratory parameters stabilized, which confirms that the prescribed treatment, which took into account the presence of comorbid lesions, and especially the circulatory system disorders, gave a positive result.

Thus, the described clinical case indicates the urgency of the various organs and systems lesions comorbidity, in particular the circulatory system, with severe clinical polymorphism problem, as their course deteriorates, number of complications, mortality and medical costs increase.

Conclusions. In the described clinical case demonstrated the development of comorbid lesions of many organs and systems, including circulatory system, in a patient with systemic lupus erythematosus. Inclusion in the treatment complex in addition to basic and drugs for the treatment lesions of circulatory system has improved the general condition of the patient, stabilized clinical and laboratory parameters, as evidenced by a prospective study during three years.

The information provided in our clinical case is consistent with the results of the literature review. Systemic lupus erythematosus needs further in-depth study due to its widespread prevalence among young and people of working age, lack of accurate knowledge about the etiology and pathogenesis of the disease, comorbid lesions of many organs and systems, including circulatory system, the development of severe and often life-threatening manifestations, the lack of clear recommendations that would predict the differentiated use of drugs taking into account comorbid syntropic lesions.

\section{References}

1. Abrahamovych U, Abrahamovych O, Nadashkevych O, Svintsitskyi A, Synenkyi O. Diagnostic value of systemic lupus erythematosus classification criteria (American college of rheumatology, 1997). International Academy Journal Web of Scholar. 2020;4(46):17-22. (Ukrainian) https://doi.org/10.31435/rsglobal_wos/30042020/7041

2. Abrahamovych UO, Abrahamovych OO, Nadashkevych ON, Svintsitsky AS, Synenkyi OV. Clarification of diagnostic criteria for systemic lupus erythematosus. Actual Problems of the Modern Medicine: Bulletin of Ukrainian Medical Stomatological Academy. 2020;20(2):4-13. (Ukrainian) ) https://doi.org/10.31718/2077-1096.20.2.4

3. Abrahamovych UO, Abrahamovych OO, Tsyhanyk LV, Farmaha ML, Synenkyi OV. A method to determine functional class of systemic lupus erythematosus in patients. World Science. 2020;5(57):10-19. (Ukrainian)

The article was received by the journal on April 7, 2021

\section{Modern View on the Problem of Systemic Lupus Erythematosus with and without Comorbid Lesions of the Circulatory System (Literature Review, Clinical Case Description) - Second Notice}

\section{Kobak, O. Abrahamovych, U. Abrahamovych, V. Chemes}

Introduction. The prevalence and incidence of systemic lupus erythematosus (SLE) in the world is significant. In recent years, there has been a tendency of the SLE prevalence increase. Despite the undoubted progress in understanding the etiology and pathogenesis of SLE, its diagnosis and treatment, the mortality of patients, including ones at young and working age, is higher than in the general population, and circulatory system lesions are ones of its main reasons in these cases.

The aim of the study. To analyze the literature, devoted to the modern view on the problem of systemic lupus erythematosus with and without comorbid lesions of the circulatory system, describe the clinical case.

Materials and methods. Content analysis, method of system and comparative analysis, bibliosemantic method of studying the current scientific studies on modern principles of diagnosis and treatment of patients with SLE are used. A clinical case is described. 
Results. A clinical case of a 43-year-old patient S., who was hospitalized for SLE, she considers herself ill for eighteen years and she has been constantly taken outpatient and periodically inpatient treatment due to the frequent deteriorations in her general condition, clinical and laboratory parameters, is described. Based on the received results of the examinations, applying the method of determining the functional class of SLE, the patient was diagnosed with a clinical diagnosis indicating comorbid lesions of various organs and systems (skin, joints, kidneys, vessels, heart, blood system, immune system, eyes). The generally accepted basic medical complex of the patient includes drugs, taking into account the lesions to the circulatory system. The conducted complex pathogenetic treatment gave a positive result.

Conclusions. In the described clinical case demonstrated the development of comorbid lesions of many organs and systems, including circulatory system, in a patient with systemic lupus erythematosus. Inclusion in the treatment complex in addition to basic and drugs for the treatment lesions of circulatory system has improved the general condition of the patient, stabilized clinical and laboratory parameters, as evidenced by a prospective study during three years. The information provided in our clinical case is consistent with the results of the literature review. Systemic lupus erythematosus needs further in-depth study due to its widespread prevalence among young and people of working age, lack of accurate knowledge about the etiology and pathogenesis of the disease, comorbid lesions of many organs and systems, including circulatory system, the development of severe and often life-threatening manifestations, the lack of clear recommendations that would predict the differentiated use of drugs taking into account comorbid syntropic lesions.

Keywords: SLE, circulatory system lesions, atherosclerosis, diagnosis and treatment of SLE.

\section{Сучасний погляд на проблему системного червоного вовчака без і з коморбідними ураженнями системи кровообігу (огляд літератури; опис клінічного випадку) - повідомлення друге}

\section{Л. О. Кобак, О. О. Абрагамович, У. О. Абрагамович, В. В. Чемес}

Вступ. Системний червоний вовчак (СЧВ) - потенційно небезпечна для життя хвороба, яка виснажує хворого, призводить до зниження працездатности, інвалідизації та, у багатьох випадках, до смерти. Захворюваність на СЧВ у світі $є$ значною. Упродовж останніх років спостерігається тенденція до зростання поширености СЧВ. Незважаючи на безсумнівні успіхи в розумінні етіології і патогенезу недуги, ії діагностики та лікування, смертність серед хворих вища, ніж у загальній популяції, а однією з основних причин у цих випадках є ураження органів системи кровообігу.

Мета. Проаналізувати літературу, присвячену сучасному погляду на проблему системного червоного вовчака без і з коморбідними ураженнями системи кровообігу, описати клінічний випадок.

Матеріали й методи. Використано контент-аналіз, метод системного та порівняльного аналізів, бібліосемантичний метод вивчення актуальних наукових досліджень щодо сучасних принципів діагностики та лікування хворих на СЧВ, описано клінічний випадок.

Результати. Описано клінічний випадок хворої Ш., 43 роки, ушпиталеної зі скаргами на біль у колінних та гомілковостопних суглобах, дрібних суглобах кистей і стіп, періодичний біль у потиличній ділянці, який імовірно спричинений, підвищенням артеріального тиску, загальну слабість; вважає себе хворою упродовж 18 років і постійно лікується з приводу СЧВ амбулаторно та періодично стаціонарно через часті погіршення загального стану та клінічно-лабораторних показників.

На основі отриманих результатів обстеження, застосувавши методику визначення функціонального класу СЧВ, хворій поставили клінічний діагноз, який вказує на коморбідне ураження різних органів і систем (шкіри, суглобів, нирок, судин, серця, системи крови, імунної системи, очей).

До загальноприйнятого базового лікувального комплексу хворій включено лікарські засоби, враховуючи ураження органів системи кровообігу: комбіновані гіпотензивні, статин, кардіопротектор. Комплексне патогенетичне лікування дало позитивний результат.

Висновки. В описаному клінічному випадку продемонстровано виникнення коморбідного ураження багатьох органів і систем, зокрема, системи кровообігу у хворої з системним червоним вовчаком. Включення до лікувального комплексу окрім базових також і лікарських засобів для лікування уражень органів системи кровообігу сприяло поліпшенню загального стану пацієнтки, стабілізації клінічно-лабораторних показників, що підтверджено проспективним дослідженням упродовж трьох років.

Інформація, подана в нашому клінічному випадку, співзвучна з результатами огляду літератури. Системний червоний вовчак важливо вивчати із огляду на його значне поширення серед людей молодого та працездатного віку, відсутність точних знань про етіологію і патогенез хвороби, виникнення коморбідного ура- 
ження багатьох органів і систем, зокрема системи кровообігу, виникнення тяжких і часто небезпечних для життя проявів, відсутність чітких рекомендацій, які б передбачали диференційоване застосування лікарських засобів із урахуванням коморбідних синтропічних уражень.

Ключові слова: СЧВ, ураження органів системи кровообігу, атеросклероз, діагностика та лікування СЧВ.

\section{Information about the authors}

1. Kobak Liubov; Danylo Halytsky Lviv National Medical University, Chair of Internal Medicine N 1 (69 Pekarska str., 79010, Lviv; +38(032)276-97-63); Assistant Professor; 7 Grabyanky str., 79053, Lviv, off. 120; + 38(067)585-20-10; k_liubov@ukr.net; https://orcid.org/0000-0002-2700-4007

2. Abrahamovych Orest; Danylo Halytsky Lviv National Medical University, Chair of Internal Medicine N 1 (69 Pekarska str., 79010, Lviv; +38(032)276-97-63); Doctor of Medical Sciences, Professor, Head of the Chair; 8 Lytovska str., 79034, Lviv,; +38(050)665-29-95, +38(032)270-44-20; docorest@gmail.com; http://orcid.org/0000-0001-6862-6809

3. Abrahamovych Ulyana; Danylo Halytsky Lviv National Medical University, Chair of Internal Medicine N 2 (69 Pekarska str., 79010, Lviv; +38(032)276-97-63); Associate Professor, PhD; 8 Lytovska str., 79034, Lviv; +38(067)757-21-09; doculyana@i.ua; https://orcid.org/0000-0003-4762-3857

4. Chemes Viktoriia; Danylo Halytsky Lviv National Medical University, Chair of Internal Medicine N 1 (69 Pekarska str., 79010, Lviv; +38(032)276-97-63); Assistant Professor; 34 Kyivska str., 79013, Lviv, off. 11; +38(098)134-92-93; viktoriya0001@gmail.com; https://orcid.org/0000-0002-9584-637X 